\title{
Influence of Water Management and Silica Application on Rice Growth and Productivity in Central Java, Indonesia
}

\author{
Adha Fatmah Siregar ${ }^{1,2}$, Ibrahim Adamy Sipahutar ${ }^{2}$, Husnain ${ }^{2}$, Heri Wibowo ${ }^{2}$, Kuniaki Sato ${ }^{1}$, \\ Toshiyuki Wakatsuki ${ }^{1} \&$ Tsugiyuki Masunaga ${ }^{1}$ \\ ${ }^{1}$ Faculty of Life and Environmental Sciences, Shimane University, Matsue, Japan \\ ${ }^{2}$ Indonesian Soil Research Institute, Bogor, Indonesia \\ Correspondence: Tsugiyuki Masunaga, Faculty of Life and Environmental Science, Shimane University, Matsue, \\ Shimane 690-8504, Japan. Tel: 81-852-32-6066. E-mail: masunaga@life.shimane-u.ac.jp
}

Received: September 16, 2016

Accepted: October 14, 2016

Online Published: November 15, 2016

doi:10.5539/jas.v8n12p86

URL: http://dx.doi.org/10.5539/jas.v8n12p86

\begin{abstract}
Rice cultivation in our study site at Central Java, Indonesia, is constrained by water scarcity and blast disease problems. A field experiment was thus conducted to evaluate the effect of water management and silicon ( $\mathrm{Si}$ ) application (with $500 \mathrm{~kg} \mathrm{ha}^{-1}$ of silica gel) on improving rice growth and productivity and blast disease infection in Jakenan, Central Java. Split plot in randomized complete block design with 4 replications was used. The results showed that two water saving methods, intermittent (IT) and aerobic rice (AR) increased rice yield compared to conventional flooding water management. Further, IT showed better root growth and hence lodging resistance and decreased blast disease infection. IT had higher yield potential compared to AR although the yield of IT and AR were not statistically different. Si application gave significant effect on reducing leaf and neck blast infection and also increased stomata density $(\mathrm{p}<0.01)$ in all water treatments. Si application did not result in increased yield but exhibited potential towards improving rice plant growth and production. Since Si fertilizer was never used in rice cultivation in Indonesia, the study reveals that IT combine with $\mathrm{Si}$ application was a suitable management for rice production in dry season in water limited Central Java region.
\end{abstract}

Keywords: blast disease, rice yield, Si application, stomata density, water management

\section{Introduction}

Indonesia is a country with a diverse tropical environment and plentiful annual precipitation, rice is widely grown and become the most important crop in Indonesia. The current condition of water management in our rice cultivation is still dominated by continuous flooding. This continuous fooding is suitable to apply in Indonesia because there is uncountable natural abundance water in the form of high rainfall in Indonesia. Conversely, certain areas such as Jakenan, Central Java province experience occasional water shortage. Annual rainfall in Indonesia is $2000-3000 \mathrm{~mm}$ year $^{-1}$ (Statistics Indonesia, 2016). However certain areas such as in Jakenan, Central Java, annual rainfal is $1100-2000 \mathrm{~mm}_{\text {year }}{ }^{-1}$.

Rainfed lowland rice in Central Java covers about 83,638 ha (Ministry of Agriculture of Republic of Indonesia, 2016) where farmers practice a high degree of crop intensification. At the onset of the rainy season, a direct seeding crop (locally they call "gogo rancah") is grown with and rainfall is the source for irrigation. Immediately after the harvest of direct seeding crop, the second tranplanted crop (walik jerami) is grown under minimum tillage in submerged water condition. Earlier studies showed that the direct seeding crop season had higher yield than the second transplanted crop season, about 3.5-6.5 $\mathrm{Mg} \mathrm{ha}^{-1}$ and 1.2-3.0 Mg ha ${ }^{-1}$ respectively (Mamaril et al., 1994; Wihardjaka et al., 1999). It showed that continous flooding as employed in the second transplanted crop season did not improve the yield. On the other hand, the direct seeding method had disadvantages such as poor seedling establishment and plant lodging occurrence which could influence on the yield (Yoshinaga, 2005).

Several cultivation methods have been adopted to improve rice production in Indonesia such as improved varieties, fertilizers, and irrigation. However, appropriate water management and silica ( $\mathrm{Si}$ ) application have not been applied in Indonesia. Related to water management, as mostly Indonesian farmers apply continuous flooding, intermittent as water management is not fully adopted. Nevertheless, previous study stated that continuous flooding can results in lodging due to the degeneration of surface roots that grow within the top $5 \mathrm{~cm}$ 
of the soil (Kar et al., 1974). Rice plants grown in aerated soil condition develop larger root systems than rice grown under continuous flooding conditions, where root die back due to lack of oxygen. Lodging is a major constraint to rice production, especially in high yielding varieties with long stem. It causes direct loss in grain yield and quality and has some indirect effects such as hindering harvesting operations (Fallah, 2000). Lodging problem could be affected by many factors i.e root growth, panicle type, plant height, starch content, silica content as well as cultivation condition (Li et al., 2009; Yang et al., 2000; Ma \& Yamaji, 2006).

Silicon ( $\mathrm{Si}$ ) is the second most abundant element after oxygen in the earth's crust and most soils contain considerable quantities of the element (Savant et al., 1997; Singer \& Munns, 2006). However, certain soils are low in plant-available Si which occurred in soil with highly weathered, leached, acidic and low in base saturation. $\mathrm{Si}$ has been shown to be a beneficial element for rice which contributes to improve resistance of rice to blast disease, lodging problem, absorption of elements such as $\mathrm{N}, \mathrm{P}$, and $\mathrm{K}$. Si is absorbed by plants as monosilicic acid $\left(\mathrm{H}_{4} \mathrm{SiO}_{4}\right)$ (Jones \& Handreck, 1967). Once absorbed, silicic acid condenses into a hard polymerized silica gel known as plant opal on epidermal surfaces (Yoshida et al., 1962).

Related to lodging resistance, as Si deposited on epidermal surface, it is supposed to stiffen stems and leaves of rice plants to improve rice plant resistance to lodging. Previous study reported that Si treatment serves to impart more strength to the stem to resist breaking than those plants in non Si treatments by increasing the number of silicated cells and $\mathrm{Si}$ content in stalks even at higher levels of nitrogen (Sadanandan \& Varghese, 1968). Si contributes to increase the mechanical strength as the culm wall and a vascular bundle become thicker and larger (Shimoyama, 1958).

Application of Si fertilizer is routine for rice cultivation in Japan, China, Brazil and other countries (Ma \& Takahashi, 2002; Korndorfer \& Lepsch, 2001). Meanwhile in Indonesia, the farmers have never used it in rice cultivation. There are some studies on soil available Si on paddy field of Indonesia. Darmawan et al. (2006) reported that over the past three decades, soil Si availability has decreased by $11-20 \%$. Husnain et al. (2008) reported that dissolved Si concentration in irrigation water in Indonesia has also decreased by $10-20 \%$ in the same period. Husnain et al. (2011) stated that paddy soils contained available Si less than $300 \mathrm{mg} \mathrm{SiO}_{2} \mathrm{~kg}^{-1}$, a deficiency criterion proposed by Sumida (1992), in 76\% out of total 92 paddy soils examined in West Sumatra, and $22.5 \%$ out of total 59 paddy soils in West Java, while in Central Java and East Java, it was less than 3\% out of total 43 paddy soils in both provinces. These studies stated increasing risks on rice cultivation such disease and pest attacks, lodging and so on that read in reduction and unstabilization of rice production, and also stated necessity of Si application for rice cultivation in Indonesia. However none of the study examining the effect of $\mathrm{Si}$ application on rice cultivation in Indonesia.

Blast disease caused by fungus Pyricularia grisea (Cooke) Sacc. [= Magnaporthe grisea (Hebert) Barr] is one of the most devastating diseases of rice plant. This disease has become increasingly important, as reflected by the most recent data indicating that 10,604 ha and 11,929 ha of rice field throughout the country were damaged by blast disease in 2010 and 2011, respectively (Wibowo, 2011). Up to the present, fungicides have been used effectively to control blast disease but not with $\mathrm{Si}$ application. Our study site has faced water scarcity and blast disease problem in rice cultivation, however up to present the farmers have been applying only continuous flooding as their water management and using fungicide for blast disease control. Therefore in the present study, we conducted a field experiment to evaluate the effect of two water saving methods and Si application on improving rice plant growth and blast disease infection in Central Java.

\section{Materials and Methods}

\subsection{Sites and Soils}

Field experiment was conducted at experimental site of Balai Penelitian Lingkungan Pertanian (Indonesian Agricultural Environment Research Institute-IAERI), Jakenan, Central Java province, Indonesia during the dry season. This location lies on $06^{\circ} 46^{\prime} 66.7^{\prime \prime} \mathrm{S}-111^{\circ} 11^{\prime} 91.4^{\prime \prime} \mathrm{E}$.

A field experiment was carried in 2014 to comparing three water management consist of continuous flooding (CF), Intermittent (IT) and Aerobic rice (AR) as main plots (Figure 1). Aerobic rice is a water saving technique for rice cultivation regions where rice is grown without ponded water because of low water availability (Bouman et al., 2007). The plots were in aerobic condition due to water scarcity before we started the water management. Then three weeks after sowing when the rain started, we started to employ three water managements. In CF management, the field was maintained with $5 \mathrm{~cm}$ depth of ponded water until flowering stage then at ripening stage of 105 days after sowing (DAS), about 15 days before harvest the field was dried and the outlet was opened. On IT management, the field was flooded about $5 \mathrm{~cm}$ water layer for 3 consecutive days then start to interrupt the water supply for 7 consecutive days with closed outlet. This pattern was conducted until panicle 
initiation stage. Then during flowering stage, the field was in flooding condition about $5 \mathrm{~cm}$ water layer and 15 days prior to harvest, the field was dried with opened outlet. In AR management, the field was in flooding condition for 28 days (tillering stage) with $5 \mathrm{~cm}$ water layer, after that we started the aerobic condition with closed inlet in following condition until harvest, i.e. when the water level drop to $15 \mathrm{~cm}$ below the soil surface, we irrigate the field until it reaches $15 \mathrm{~cm} .15$ days prior to harvest, the field was dried with opened outlet. Field water tube was installed in AR treatment to monitor the water level.

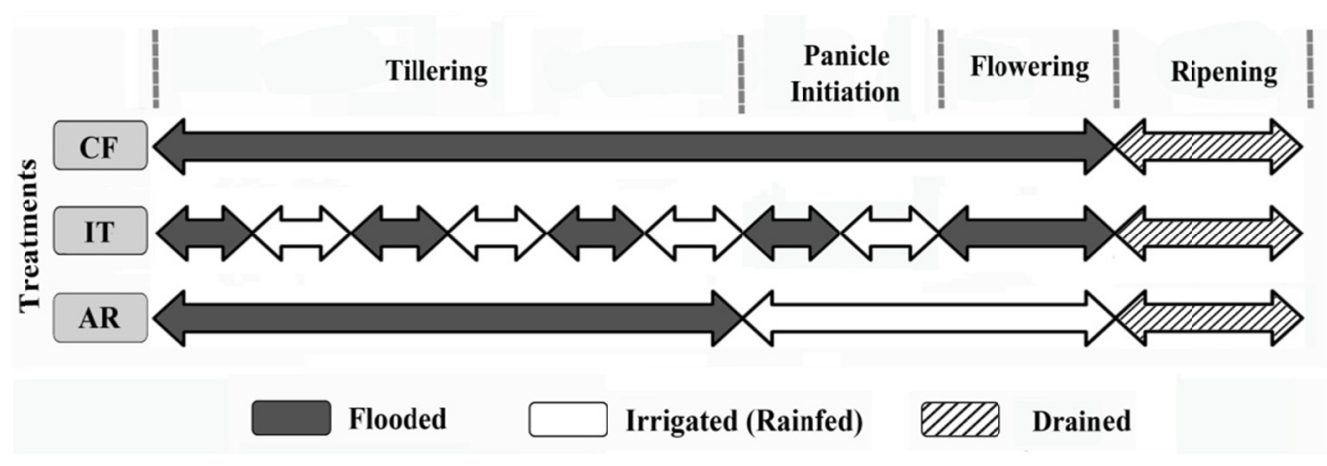

Figure 1. Diagram of water management

Note. CF: $5 \mathrm{~cm}$ depth of water until 105 DAS then dried for 15 days before harvest. IT: the field was flooded with $5 \mathrm{~cm}$ depth for 3 days then interrupted water supply for 7 days (closed outlet), with this pattern employed until panicle initiation. At flowering stage, IT was in flooding condition with $5 \mathrm{~cm}$ depth then the field was dried 15 days before harvest (opened outlet). AR, the field was flooded with $5 \mathrm{~cm}$ depth for 28 days (tillering stage) then the field was set in aerobic condition until flowering (keeping water level higher than the soil depth of 15 $\mathrm{cm}$ ), then the field was dried 15 days before harvest.

Direct seeding was employed, therefore the plots were dried for three weeks before water managements were started.

The sub plot was characterized by two treatments including $\mathrm{Si}+$ and $\mathrm{Si}$ - (with and without $\mathrm{Si}$ fertilizer). We used local silica gel "Silica gel White" sold as desiccant by IMCO Co. as Si fertilizer. This local silica gel has the spherical shape with the diameter of 2-4 mm and has lower water solubility, $0.1 \mathrm{gg}^{-1} 24 \mathrm{~h}^{-1}$ compare to Japanese Si fertilizer, Super Inergia, $0.3 \mathrm{gg}^{-1} 24 \mathrm{~h}^{-1}$. A rice variety "Ciherang" was used for this study as it is a very common variety recommended by Ministry of Agriculture of Republic of Indonesia. Ciherang rice variety which released in 2000 is an indica rice categorized as short-duration variety (116-120 days) with average yield of 6 ton $\mathrm{ha}^{-1}$ and is suitable for planting in rainy and dry season. Split plot in randomized complete block design with 4 replications was used. The plot size was $4 \mathrm{~m} \times 5 \mathrm{~m}$ for each treatments. During plotting, we installed plastic sheet about $30 \mathrm{~cm}$ into the soil between treatments at the border sides to avoid contamination. Each plots had an inlet and outlet for irrigation.

Initial soil properties (Table 1) showed that the soil in experimental site had low soil available silica below the critical level proposed by Sumida (1992) and Dobermann and Fairhurst (2000): 300 and $86 \mathrm{mg} \mathrm{SiO}_{2} \mathrm{~kg}^{-1}$ respectively. The parent material of the experimental site is alluvial (Kadar \& Sudijono, 1993). 
Table 1. Initial soil properties

\begin{tabular}{lll}
\hline Soil Properties & Values & Criteria $^{\mathrm{a}}$ \\
\hline $\mathrm{pH}\left(\mathrm{H}_{2} \mathrm{O}\right)$ & 4.90 & Acid \\
Total $\mathrm{C}\left(\mathrm{g} \mathrm{kg}^{-1}\right)$ & 7.6 & Very low \\
Total N $\left(\mathrm{g} \mathrm{kg}^{-1}\right)$ & 0.3 & Very low \\
Exchangeable cations $\left(\mathrm{cmol}_{\mathrm{c}} \mathrm{kg}^{-1}\right)$ & & \\
$\mathrm{Ca}$ & 2.14 & Low \\
$\mathrm{K}$ & 0.04 & Very low \\
$\mathrm{Mg}$ & 0.25 & Very low \\
$\mathrm{Na}$ & 0.15 & Low \\
Available Si $\left(\mathrm{mg} \mathrm{SiO}_{2} \mathrm{~kg}^{-1}\right)$ & 31.3 & Low \\
\hline
\end{tabular}

Note. ${ }^{\mathrm{a}}$ Refered to Indonesian Soil Research Institute (2005).

${ }^{\mathrm{b}}$ Refered to Sumida (1992).

\subsection{Plant Cultivation}

Rice cultivation was conducted with direct seeding method due to water scarcity with row spacing $20 \mathrm{~cm} \times 20$ $\mathrm{cm}$. Land preparation was done by conventional tillage. Silica gel was applied before sowing the seed as $500 \mathrm{~kg}$ $\mathrm{ha}^{-1}$. The rainfall collected in the pond is used for irrigation. The fertilizer dosage was $350 \mathrm{~kg} \mathrm{ha}^{-1}$ of Urea, 100 $\mathrm{kg} \mathrm{ha}^{-1}$ of SP-36 and $50 \mathrm{~kg} \mathrm{ha}^{-1}$ of KCl. Urea and $\mathrm{KCl}$ fertilizer were applied two times, at 24 DAS (days after sowing) and 50 DAS. Meanwhile for SP-36 was applied one time at 24 DAS. During this cultivation we did not apply any fungicide for blast disease.

\subsection{Sampling and Analysis}

The available Si for initial soil analysis was determined using the acetate buffer method (Imaizumi \& Yoshida, 1958). Soil samples were extracted in $1 \mathrm{~mol} \mathrm{~L}^{-1}$ acetate buffer ( $\left.\mathrm{pH} 4.0\right)$ at a ratio of $1: 10$ for $5 \mathrm{~h}$ at $40{ }^{\circ} \mathrm{C}$ with occasional shaking. Although Sumida (1991) reported that the acetate buffer method was not suitable for soils previously amended with silicate fertilizer, this was not a problem because no silicate fertilizer had been applied previously in this experimental site. The extracted Si content in the soil samples was determined using atomic absorption spectrophotometer (Z-5000; Hitachi, Tokyo, Japan). The soil $\mathrm{pH}$ was measured using the glass electrode method with a soil:water ratio of 1:2.5 (IITA, 1979; McLean, 1982). For determining soil exchangeable cation, soil samples were extracted with $1 \mathrm{M} \mathrm{NH}_{4} \mathrm{OAc}$ at $\mathrm{pH} 7$ (Thomas, 1982) and measured by Inductively Coupled Plasma (ICPE-9000 Shimadzu Co, Kyoto, Japan).

Rice leaf samples, the Y-leaf, were collected at 50 DAS, 90 DAS and harvest then analyzed for total Si content. Samples were digested with $\mathrm{HNO}_{3}$ in a high pressure Tefflon Vessel (Quaker et al., 1970; Koyama \& Sutoh, 1987). After heating and digest in $160^{\circ} \mathrm{C}$ for 5 hours and cooling overnight, then adding $\mathrm{HF} 10 \%$ and $\mathrm{H}_{3} \mathrm{BO}_{3} 4 \%$. The extracted Si content in the plant samples was determined using atomic absorption spectrophotometer (Z-5000; Hitachi, Tokyo, Japan).

Lodging resistance was measured using Force Gauge at 75 and 110 DAS. 10 plant samples were selected from each treatment for lodging resistance measurement. To measured lodging resistance, the stem was bent at $15 \mathrm{~cm}$ from the surface of the soil to establish an angle $45^{\circ}$ (Yoshinaga, 2005).

Stomata samples were collected with clear nail polish method (Radoglou \& Jarvis, 1990) at 50, 80 and 95 DAS. Epidermal impression was prepared by coating the rice leaf surface with nail polish which was peeled off, once nail polish was dried, it was mounted onto a slide by a cello tape. The impression approach was used to determine the number of stomata. The sample was collected only from abaxial leaf surface since the abaxial leaf surface has greater stomata density than the adaxial surface exposed to sun light (Martin \& Glover, 2007). Less stomata density on adaxial surface could decrease leaf water transpiration rate (Wang \& Clarke, 1993b). These impressions were observed by light microscopy (Olympus BX51) and number of stomata were investigated in a field of $0.04 \mathrm{~mm}^{2}$ then we calculated the number of stomata per $\mathrm{mm}^{2}$ leaf area.

Blast disease infection was observed at 50 and 95 DAS for leaf blast and 95 DAS and harvest for neck blast. 10 plant samples were observed from each treatment for blast disease infection. We observed leaf blast disease infection using score value which employed by IRRI System (1996). Score value for each symptom category of blast disease are 0 : no lessions; 1: small brown speaks of pin point size or large brown speak without speculating 
centre; 2: small round dish to slightly elongated necrotic grey spots about 1-2 $\mathrm{mm}$ in diameter with distinct brown margin lessions are mostly found on upper leaves; 3: same as score 2, but significant number of lesions are on upper leaves; 4: typical susceptible blast lesion, $3 \mathrm{~mm}$ or longer infecting lesions than $2 \%$ of leaf area; 5 : typical blast lesion infecting $2-10 \%$ of leaf area; 6 : typical blast lesion infecting $11-25 \%$ of the leaf area; 7 : typical blast lesion infecting $26-50 \%$ of the leaf area; 8 : typical blast lesion infecting $51-75 \%$ of the leaf area and 9: more than $75 \%$ leaf are affected.

Normality test was conducted before analyze the effect of treatments and the outlier data was excluded. To determine the influence of water managements and Si application on parameters, data were statistically analyzed by two way analysis of variance (ANOVA). Significances among the treatments were determined by Tukey's honestly significant difference test at $\mathrm{p}<0.05$. All statistical analysis was performed using IBM SPSS Statistic version 20.0 (IBM SPSS, 2011. Chicago IL, USA).

\section{Results}

\subsection{Plant Growth}

Table 2 shows the effects of treatments on plant growth as root weight, shoot weight and number of tillers. On root weight, IT was higher by 25 and $43 \%$ for $\mathrm{Si}+$ and 15 and $16 \%$ for Si- comparing to CF and AR respectively. IT management also showed higher shoot weight than CF and 5\% significant with AR (Table 2).

On Si application, there was no significant difference on root weight, shoot weight and number of tillers.

Table 2. Effect of treatments on root and shoot weight, and number of tillers at harvest

\begin{tabular}{|c|c|c|c|}
\hline \multirow{2}{*}{ Si application } & \multicolumn{3}{|c|}{ Water management } \\
\hline & $\mathrm{CF}$ & IT & $\mathrm{AR}$ \\
\hline \multicolumn{4}{|l|}{$\operatorname{Root}\left(\mathrm{g} \mathrm{m}^{-2}\right)$} \\
\hline $\mathrm{Si}+$ & $360 \pm 26.2 \mathrm{ab}$ & $449 \pm 96.5 b$ & $314 \pm 46.8 \mathrm{a}$ \\
\hline Si- & $349 \pm 66.1 \mathrm{ab}$ & $401 \pm 72.6 b$ & $344 \pm 37.2 \mathrm{a}$ \\
\hline \multicolumn{4}{|l|}{ Shoot $\left(\mathrm{kg} \mathrm{m}^{-2}\right)$} \\
\hline $\mathrm{Si}+$ & $2 \pm 0.5 \mathrm{ab}$ & $2.2 \pm 0.4 b$ & $1.8 \pm 0.2 \mathrm{a}$ \\
\hline Si- & $2 \pm 0.2 \mathrm{ab}$ & $2.1 \pm 0.3 b$ & $1.6 \pm 0.1 \mathrm{a}$ \\
\hline \multicolumn{4}{|c|}{ Number of tillers (per $\left.\mathrm{m}^{2}\right)$} \\
\hline $\mathrm{Si}+$ & $349 \pm 15.8 b$ & $304 \pm 41.3 b$ & $274 \pm 36.5 \mathrm{a}$ \\
\hline Si- & $358 \pm 23.5 b$ & $356 \pm 44.8 b$ & $279 \pm 14.9 \mathrm{a}$ \\
\hline
\end{tabular}

Note. Means followed by the same latter do not differ significantly at $5 \%$; No statistical difference was observed between Si treatments; \pm denotes standard deviation.

\subsection{Leaf and Neck Blast Infection}

On the effect of Si application, the leaf blast infection at 50 and 95 DAS was the lowest in IT (Figure 2). Si application gave significant effect $(\mathrm{p}<0.01)$ on reducing leaf blast infection throughout the observation periods in all water management (Figure 2). Si application decreased the leaf blast infection by 62,45 and $45 \%$ at 50 DAS and 62,29 and $48 \%$ at 95 DAS for CF, IT and AR management, respectively. Si application gave significant effect $(\mathrm{p}<0.01)$ on reducing neck blast infection throughout the observation periods in all water management as well as it did for the leaf blast (Figure 3). Si application could decrease significantly $(p<0.01)$ the neck blast infection by 72,86 and $80 \%$ at 95 DAS and 75,69 , and $80 \%$ at harvest for CF, IT and AR management comparing to Si- treatments, respectively. Describe, neck blast infection was severer and effect of $\mathrm{Si}$ was clearer. Si application clearly showed significant effect on decreasing both leaf and neck blast in the present study.

On the effect of water management, IT had effect on reducing leaf and neck blast infection.

\subsection{Rice Yield}

The result showed that water management showed significant effect on yield. The rice yield in IT increased 29 and $4 \%$ comparing to $\mathrm{CF}$ and $\mathrm{AR}$ in $\mathrm{Si}+$ treatments, and 60 and $5 \%$ to $\mathrm{CF}$ and $\mathrm{AR}$ in $\mathrm{Si}$ - treatment, respectively. We also observed yield component that probably contributed the yield difference among treatments. The 1000 -grains weight of IT and AR were not significantly different but were higher than that of CF (Table 3). 
Meanwhile on Si application, there was no significant difference on rice yield.

\subsection{Lodging Resistance}

For The result of lodging resistance at 95 and 110 DAS is shown in Figure 4. The lodging resistance tended to decrease from 95 to 110 DAS in all water management because the shoot weight increase with grain filling and leaf senescence occurs (Yoshida, 1981). IT showed slightly higher lodging resistance than AR did at 95 DAS. Meanwhile, Si application showed no significant effect in all the water management.

\subsection{Stomata Density and Length}

In all water management, Si application increased stomata density by $8-44 \%$ for all the observation period. Meanwhile on stomata length, Si application had no significant effect. Generally in IT, the increase rate was higher than CF and AR. IT and AR had higher stomata density than CF in both Si treatment condition at 80 DAS (Table 4).

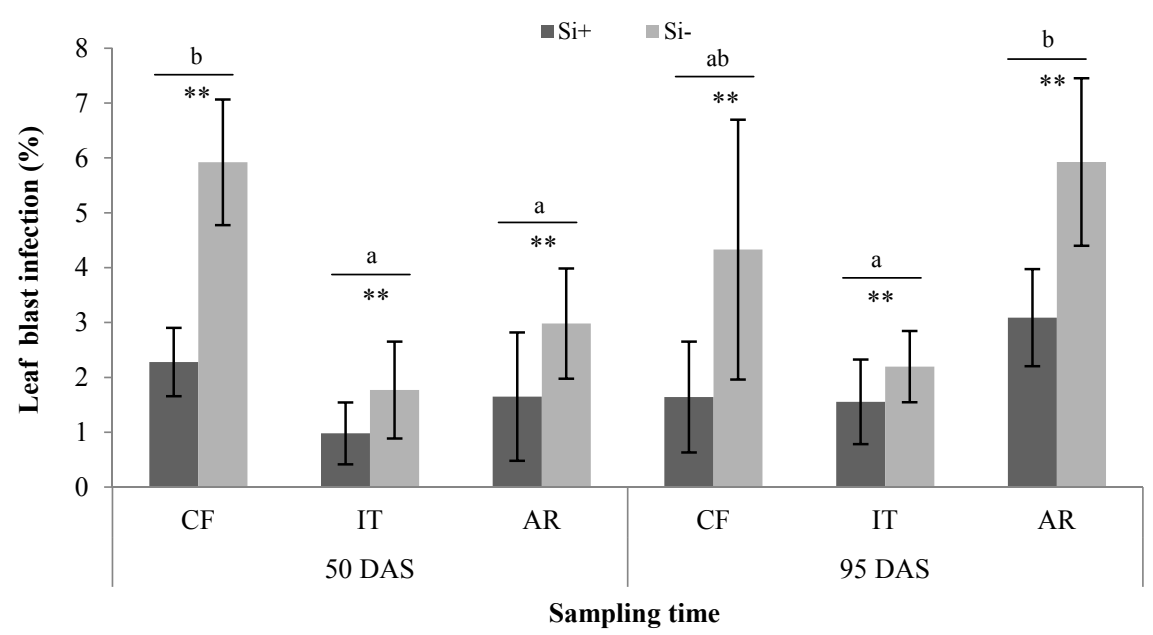

Figure 2. Effect of treatments on leaf blast infection

Note. The different alphabet letters indicates significant difference among water managements each sampling time; ** Significant difference at $\mathrm{p}<0.01$ between $\mathrm{Si}+$ and $\mathrm{Si}-$ at each sampling time; Error bars indicate standard deviation among the mean values.

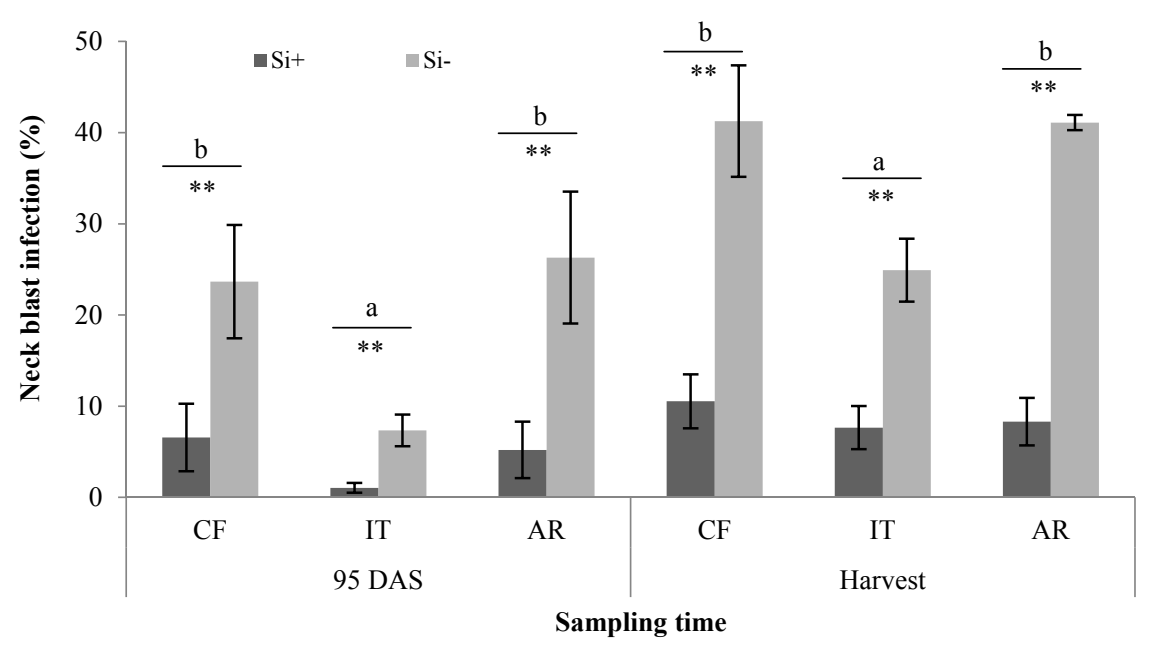

Figure 3. Effect of treatments on neck blast infection

Note. The different alphabet letters indicates significant difference among water managements each sampling time; ** Significant difference at $\mathrm{p}<0.01$ between $\mathrm{Si}+$ and $\mathrm{Si}-$ at each sampling time; Error bars indicate standard deviation among the mean values. 
Table 3. Effect of treatments on rice yield and yield component

\begin{tabular}{llll}
\hline \multirow{2}{*}{ Si application } & \multicolumn{3}{c}{ Water management } \\
\cline { 2 - 4 } & $\mathrm{CF}$ & $\mathrm{IT}$ & $\mathrm{AR}$ \\
\hline Yield $\left(\mathrm{g} \mathrm{m}^{-2}\right)$ & $423 \pm 41.5 \mathrm{a}$ & $547 \pm 39.7 \mathrm{~b}$ & $524 \pm 28.4 \mathrm{~b}$ \\
$\mathrm{Si} \pm$ & $332 \pm 44.7 \mathrm{a}$ & $530 \pm 18.0 \mathrm{~b}$ & $507 \pm 42.3 \mathrm{~b}$ \\
$\mathrm{Si}-$ & & & \\
\hline The 1000-grains weight $(g)$ & $30 \pm 1.5 \mathrm{a}$ & $32 \pm 0.8 \mathrm{~b}$ & $31 \pm 0.9 \mathrm{~b}$ \\
$\mathrm{Si} \pm$ & $29 \pm 1.9 \mathrm{a}$ & $31 \pm 0.6 \mathrm{~b}$ & $30 \pm 0.8 \mathrm{~b}$ \\
$\mathrm{Si}$ - & & & \\
\hline
\end{tabular}

Note. Means followed by the same latter do not differ significantly at 5\%; No statistical difference was observed between $\mathrm{Si}$ treatments; \pm denotes standard deviation.

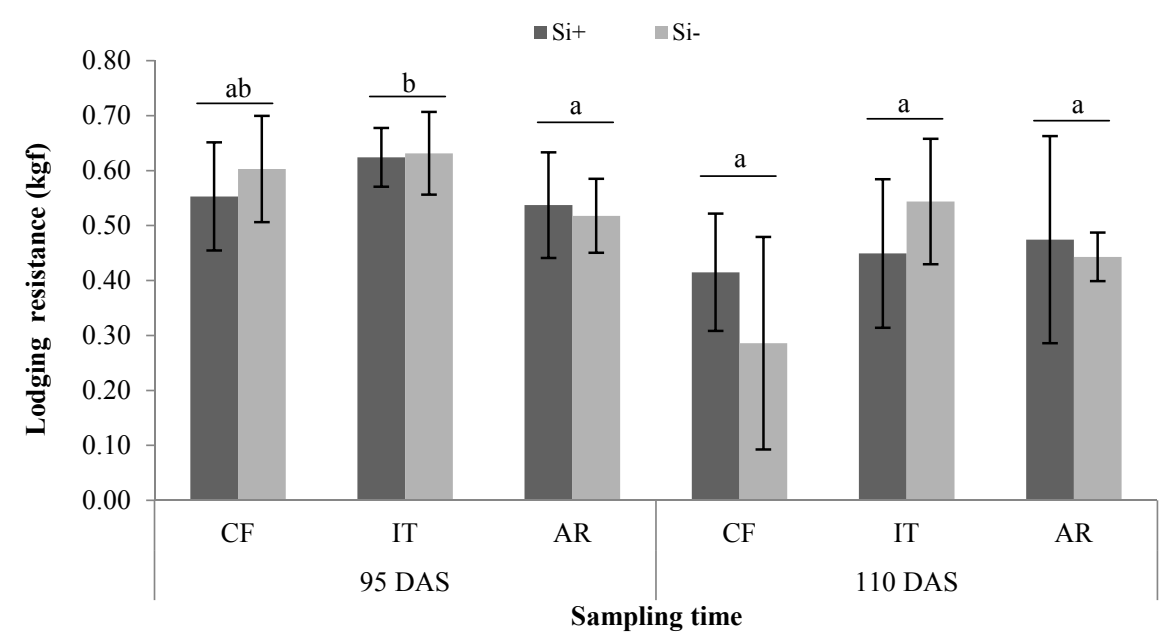

Figure 4. Effect of treatments on lodging resistance

Note. The different alphabet letters indicates significant difference among water managements each sampling time; There was no significant difference between $\mathrm{Si}+$ and $\mathrm{Si}$ - at each sampling time; Error bars indicate standard deviation among the mean values.

Table 4. Effect of treatments on stomata density and length

\begin{tabular}{|c|c|c|c|c|c|c|c|c|c|}
\hline \multirow{3}{*}{ Si Application } & \multicolumn{9}{|c|}{ Water management } \\
\hline & \multicolumn{3}{|c|}{50 DAS } & \multicolumn{3}{|c|}{80 DAS } & \multicolumn{3}{|c|}{95 DAS } \\
\hline & $\mathrm{CF}$ & IT & AR & $\overline{\mathrm{CF}}$ & IT & AR & $\mathrm{CF}$ & IT & AR \\
\hline \multicolumn{10}{|c|}{ Stomata density $\left(\right.$ per $\left.\mathrm{mm}^{2}\right)$} \\
\hline $\mathrm{Si}+$ & $591 \pm 76 a$ & $610 \pm 33 a$ & $534 \pm 62 \mathrm{a}$ & $668 \pm 49 a$ & $795 \pm 45 \mathrm{c}$ & $724 \pm 5 b$ & $630 \pm 21 \mathrm{a}$ & $721 \pm 19 a$ & $730 \pm 14 a$ \\
\hline \multirow[t]{2}{*}{$\mathrm{Si}-$} & $464 \pm 35 \mathrm{a}$ & $435 \pm 53 a$ & $588 \pm 25 \mathrm{a}$ & $519 \pm 45 a$ & $608 \pm 29 c$ & $588 \pm 25 b$ & $580 \pm 35 \mathrm{a}$ & $536 \pm 26 a$ & $508 \pm 43 a$ \\
\hline & $* *$ & $* *$ & $* *$ & $* *$ & $* *$ & $* *$ & $* *$ & $* *$ & $* *$ \\
\hline \multicolumn{10}{|c|}{ Stomata length $\left(\times 10^{-3} \mathrm{~mm}\right)$} \\
\hline $\mathrm{Si}+$ & $11 \pm 0.2 \mathrm{a}$ & $12 \pm 0.6 \mathrm{a}$ & $15 \pm 3.2 \mathrm{~b}$ & $14 \pm 0.7 \mathrm{a}$ & $14 \pm 0.4 \mathrm{~b}$ & $14 \pm 0.4 \mathrm{ab}$ & $11 \pm 0.4 \mathrm{a}$ & $13 \pm 0.7 \mathrm{~b}$ & $13 \pm 0.5 b$ \\
\hline \multirow[t]{2}{*}{$\mathrm{Si}-$} & $12 \pm 0.7 \mathrm{a}$ & $13 \pm 0.6 \mathrm{a}$ & $14 \pm 0.7 \mathrm{~b}$ & $13 \pm 0.3 \mathrm{a}$ & $14 \pm 0.2 b$ & $13 \pm 0.6 \mathrm{ab}$ & $13 \pm 0.1 \mathrm{a}$ & $12 \pm 0.4 \mathrm{~b}$ & $13 \pm 0.5 b$ \\
\hline & ns & ns & ns & ns & ns & $\mathrm{ns}$ & ns & ns & $\mathrm{ns}$ \\
\hline
\end{tabular}

$\overline{\text { Note. Means followed by the same latter do not differ significantly at 5\%; No statistical difference was observed }}$ between Si treatments; \pm denotes standard deviation. 


\section{Discussion}

The result showed that IT had higher root weight that possibly due to better soil aeration which could increase root growth. Xu et al. (2007) stated that root biomass in intermittent irrigation was higher than in continuous flooding. Moreover, Mishra (2012) found that intermittent irrigation positively affected root length, density and total root mass in rice growth. These were consistent with the results of the present study. On the other hand, several works reported possible negative effects of $\mathrm{CF}$ and AR water condition on plant growth. Continuous flooding could degenerate and has been proved to be detrimental to the rice root growth (Kar et al., 1974; Sahrawat, 2000). Low soil water availability and high soil impedance of paddy field could inhibit root growth (Taylor \& Gardner, 1963; Cornish et al., 1984). Therefore as the shoot drives water uptake through a plant, root system, properties and distribution include the weight, ultimately determine plant access to water and thus set limit on shoot weight and functioning (Nardini et al., 2002).

Furthermore, higher shoot weigh in IT might be due to better root growth which could enhance water and nutrient uptakes for its higher shoot growth in IT. On number of tillers, CF and IT had higher number of tiller than did AR. Lower number of tiller in AR could be related to the low soil moisture which could induced impaired and reduced tillering numbers (Yoshida, 1981).

Related to blast disease infection, IT had lesser leaf and neck blast infection. This might be because IT had a less favorable soil moisture condition for blast disease life-cycles (Chapagain et al., 2011). In IT, the soil moisture condition repeteadly changed from submerged to non-saturated, rather dry. When the soil became unsaturated, the soil temperature could increase in the day time and could lower the relative humidity in the fields comparing to that in CF. The lower relative humidity were less favorable for rice disease and insect pest (Bin, 2008). Moreover, Xuan and Gergon (2016) stated that to reduce blast development, intermittent irrigation during seedling stage was also effective.

In the aspect of soil moisture condition, AR must have been the driest and should have an advantage in blast infection. However, AR tended to have higher leaf and neck blast infection than IT did. This could be attributed in the difference of rice Si uptake in each water management. Aerobic soil condition observed in AR could decrease the solubility of Si (Winslow, 1995) which could reduce rice Si uptake. Meanwhile the soil in IT treatment repeatedly experienced submerged condition which increases soil Si availability (Fageria et al., 2011).

Regarding with rice Si uptake, IT had higher leaf Si content $(\mathrm{p}<0.05)$ than CF and AR at 95 DAS and than CF at harvest (Figure 5). IT water condition could enhance plant Si uptake through both better root growth and higher soil $\mathrm{Si}$ availability. Then, higher plant $\mathrm{Si}$ content probably reduced blast disease infection as $\mathrm{Ma}$ and Takahashi (2002) reviewed several literatures.

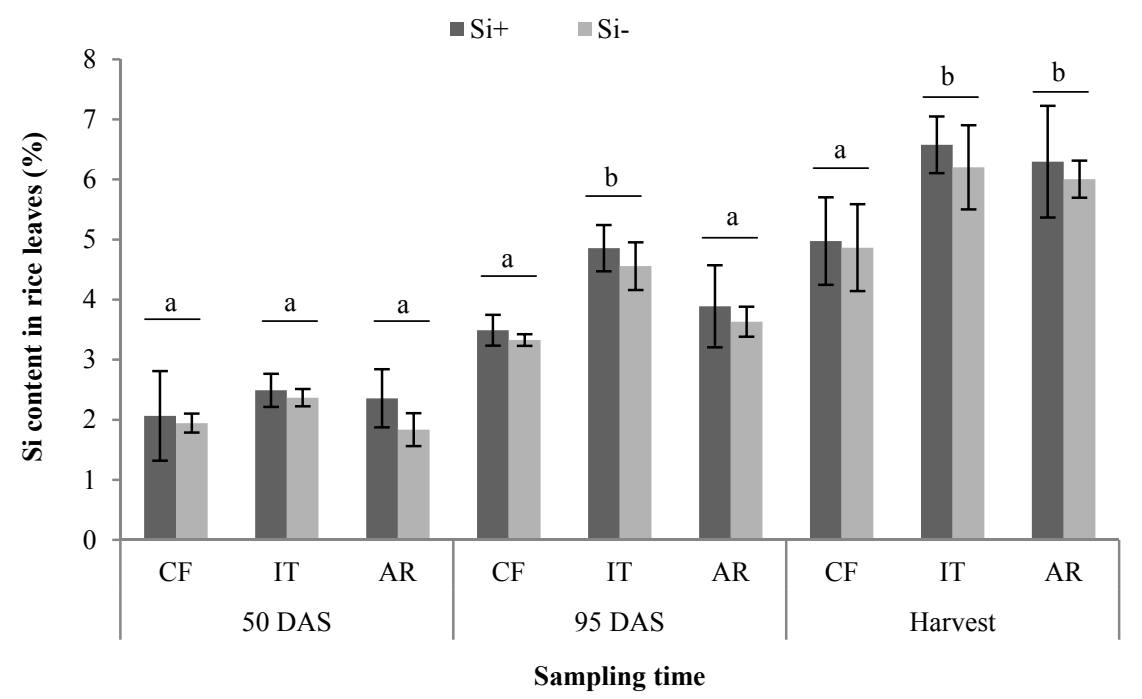

Figure 5. Effect of treatments on Si content in rice leaves

Note. The different alphabet letters indicates significant difference among water managements each sampling time; There was no significant difference between $\mathrm{Si}+$ and $\mathrm{Si}$ - at each sampling time; Error bars indicate standard deviation among the mean values. 
Si application clearly gave the positive effect on reducing leaf blast infection on Ciherang variety, which agreed with the research results found in West Java (Siregar et al., 2016) where soil Si available was $426.54 \mathrm{mg} \mathrm{\textrm {SiO } _ { 2 }}$ $\mathrm{kg}^{-1}$ and for the other rice varieties in different countries such as in Japan, Brazil and Thailand (Seebold, 1988; Prabhu et al., 2001; Hayasaka et al., 2005; Wattanapayapkul et al., 2011). The present result showed that Si application showed clearer effect on reducing blast disease on rice plant with soil Si available is $31.27 \mathrm{mg} \mathrm{SiO}_{2}$

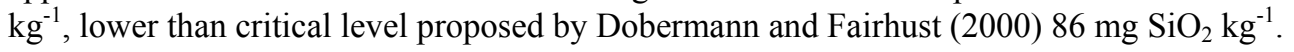

The Si content in rice leaves was not significant different between $\mathrm{Si}$ treatment but tended to increase on $\mathrm{Si}+$ treatment (Figure 5). The mechanism of Si-induced blast resistance has been hypothesized that silicic acid uptake by plant form hard glass-like coating of polymerized $\mathrm{SiO}_{2}$, so called plant opal, on the epidermal surfaces and this coating will acts as a physical barrier which could block the fungi penetration (Yoshida, 1965; Winslow et al., 1997; Datnoff \& Rodrigues, 2005).

In rice cultivation, the yield could be affected by water and nutrients availability (Dobermann \& Fairhust, 2000) and to achieve sufficient amounts of these factors, rice plant requires a good rooting ability. Related to root condition, where IT had higher root growth (Table 2) as well as higher yield compare to CF and AR did (Table 3). Higher yield achieved in IT treatment could due to better root growth which could enhance water and nutrient uptake contributing to higher photosynthetic rate (Osaki et al., 1997).

Beside the fact that IT had better root growth, overall IT management also had the lowest leaf and neck blast infection compared to AR and CF management throughout observation period. As water condition in IT with better root growth, it could enhance higher Si uptake which followed by improving the blast resistance of rice plant in IT. The present study showed significant negative correlation between neck blast infection and the rice yield $(r=0.64$ and $r=0.65$ at $\mathrm{Si}+$ and $\mathrm{Si}$ - treatment respectively; $\mathrm{p}<0.05)$ (Figure 6). In general, it is known that blast disease is one of the most destructive for rice production. And neck blast is considered the most important symptom of rice blast because it is more closely related to yield loss (Zhu et al., 2005). Bastiaans (1993) reported that leaf blast could reduce the photosynthetic rate. This meant leaf blast also possibly reduce rice growth and yield. However, blast infection could not fully explain the difference on rice yield shown in Table 3.

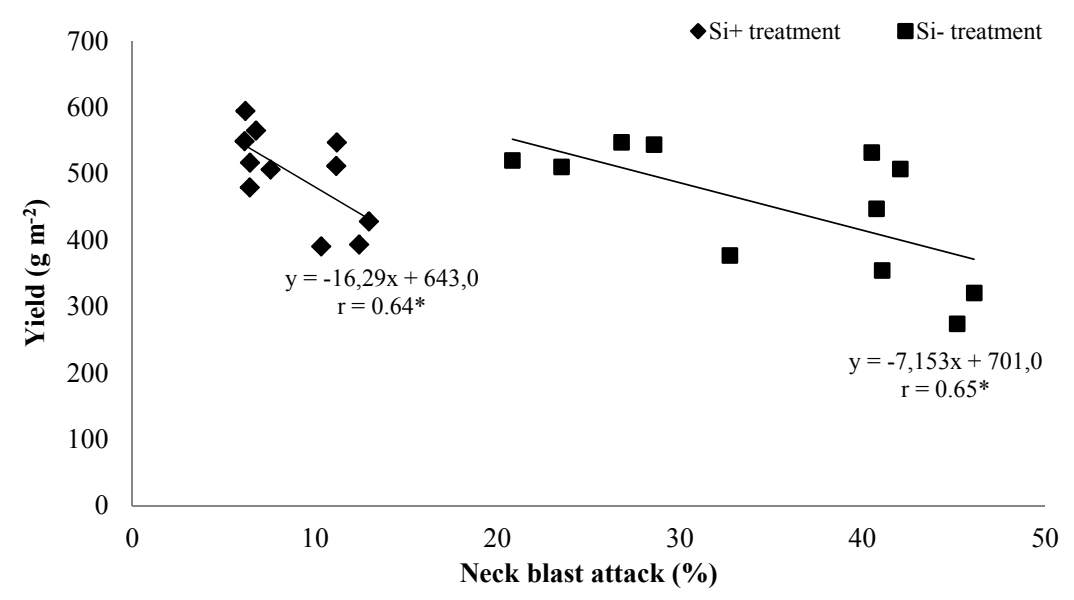

Figure 6. Correlation between neck blast attack with the yield $(p<0.05)$

Moreover, IT showed higher stomata density compare to CF and AR (Table 4). This result could be took part on increasing the rice yield in IT. Some previous studies (Jones, 1992; Ishimaru et al., 2001) stated that the improvement on morphological characteristics of stomata such as stomata density could improve the yield.

In this present study, although IT had higher yield but it was not significant different with AR. This result might be related with the Si content in rice leaf and the transpiration rate. As shown in Figure 5, the Si content in rice leaves at harvest was not significant different between the IT and AR and higher compare to CF. Transpiration plays a certain role in translocation and accumulation of Si to the tops of rice, i.e leaves and husk, where the transpiration rate is higher at those plant organs. Along with higher Si content in leaves, it will stimulate the translocation of photoassimilated $\mathrm{CO}_{2}$ to the panicle in rice (Ma \& Takahasi, 2002) which could influence on the yield. 
IT management showed possibility to improve lodging resistance, which might be due to better root growth. The higher lodging resistance in IT was attributed to higher root weight (Table 2). Previous studies stated that root system was responsible for lodging in rice plant. Higher lodging resistance would require heavier roots and deeper root system (Terashima et al., 1994; Feng-zhuan at al., 2010). Therefore with better root growth in IT management it could improve lodging resistant of rice plant. Meanwhile, Si application showed no significant relationship with the lodging resistance in the present study.

Stomata density showed that generally the increase rate of stomata in IT was higher. However at 80 DAS, showed that IT and AR had higher stomata density than CF in both Si treatment condition (Table 4). On stomata length, the result showed that IT and AR tend to have higher stomata length than CF. It probably indicated the adaptation of rice plant to water limited condition as reported by Spence et al. (1986) and Kramer (1988). The present study showed that $\mathrm{Si}$ application clearly gave the positive effect on increasing stomata density on Ciherang variety throughout observation, which agreed with the previous results found in West Java (Siregar et al., 2016). These are in line with the result from Dias et al. (2014), stated that there is indication of Si addition promoted the development of higher stomata density. Si application combined with water saving condition had the highest effect on stomata density increment.

Some of previous studies presumed that Si plays a role in decreasing the transpiration rate by changing the stomata movement rather than affecting its morphology and density (Gao et al., 2006; Zargar \& Agnihotri, 2013). According to Marin (2003) benefits of $\mathrm{Si}$ application to plants includes direct effect such as structural development and indirect effect like in increasing the photosynthetic rate by improving stomata density. Moreover, apart from the present result that showed Si could improve stomata density, Si also could keep the leaf erect as it is deposited in the leaf therefore Si could stimulate canopy photosynthesis by improving light interception (Ma \& Takahasi, 2002).

\section{Conclusions}

The present study demonstrated that two water saving management increased rice yield comparing with conventional flooding water management. This probable attributed to better grain filling status shown of the 1000-grains weight. Besides this result, IT had better root growth that possibly leaded to improve lodging resistance and shoot growth and also decreased blast disease infection. These results suggested that IT had higher yield potential comparing to AR although the rice yield of IT and AR were not statistically different in this time. This result might be due to Si uptake which IT and AR had higher Si content in leaves, and could promoted on photosynthetic rate.

On Si application, it clearly improved plant resistance to both leaf and neck blast infection and increased stomata density in all water treatments. In this time, these phenomena did not result in the higher yield but exhibited potential improving rice plant growth and production in Central Java region. In conclusion, IT combine with Si application was a suitable management for rice production in dry season in water limited Central Java region.

\section{Acknowledgements}

This work was supported by JSPS KAKENHI Grant Number 24405047, 25257405.

\section{References}

Bastiaans, L. (1993). Effect of leaf blast on photosynthesis of rice. 1. Leaf photosynthesis. Netherlands Journal of Plant Pathology, 99, 197-203. http://dx.doi.org/10.1007/BF01974664

Bin, D. (2008). Study on environmental implication of water saving irrigation in Zhanghe Irrigation System. Wuhan University. The project report submitted to Regional Office for Asia and the Pacific, FAO. Retrieved March 28, 2016, from http://www.fao.org/nr/water/espim/reference/study_environment_water_saving.pdf

Bouman, B. A. M., Lampayan, R. M., \& Tuong, T. P. (2007). Water management in irrigated rice: Coping with water scarcity. Philiphine: International Rice Research Institute (IRRI).

Chapagain, T., Riseman, A., \& Yamaji, E. (2011). Achieving more with less water: Alternate wet and dry irrigation (AWDI) as an alternative to the conventional water management practices in rice farming. Journal of Agricultural Science, 3(3), 3-13. http://dx.doi.org/10.5539.jas.v3n3p3

Cornish, P. S., So, H. B., \& McWilliam, J. R. (1984). Effects of soil bulk-density and water regime on root-growth and uptake of phosphorus by ryegrass. Aust J Agric Res, 35, 631-644. http://dx.doi.org/ 10.1071/AR9840631 
Darmawan, Kyuma, K., Saleh, A., Subagjo, H., Masunaga, T., \& Wakatsuki, T. (2006). Effect of long-term intensive rice cultivation on the available silica content of sawah soils: Java Island, Indonesia. Soil Sci Plant Nutr, 52, 745-753. http://dx.doi.org/10.1111/j.1747-0765.2006.00089.x

Datnoff, L. E., \& Rodrigues, F. A. (2005). The Role of silicon in suppressing rice diseases. APSnet Features. http://dx.doi.org/10.1094/APSnetFeature-2005-0205

Dias, G. M. G., Soares, J. D. R., Pasqual, M., Silva, R. A. L., Rodrigues, L. C. A., Pereire, F. J., \& Castro, E. M. (2014). Photosynthesis and leaf anatomy of Anthurium cv. Rubi plantlets cultured in vitro under different silicon (Si) concentrations. AJCS, 8(8), 1160-1167.

Dobermann, A., \& Fairhurst, T. (2000). Rice: Nutrient disorders and nutrient management. Singapore and Los Banõs: Potash \& Phosphate Institute (PPI), Potash \& Phosphate Inst. of Canada (PPIC), and Int. Rice Res. Inst. (IRRI), Los Banõs, Philippine.

Fageria, N. K., Carvalho, G. D., Santos, A. B., Ferreire, E. P. B., \& Knupp, A. M. (2011). Chemistry of lowland rice soils and nutrient availability. Communications in Soil Science and Plant Analysis, 42, 1913-1933. http://dx.doi.org/10.1080/00103624.2011.591467

Fallah, A. (2000). Effects of silicon and nitrogen on growth, lodging and spikelet filling in rice (Oryza sativa L.) (Unpublished doctoral dissertation). University of the Philippines, Los Baños, Philippines.

Feng-zhuan, Z., Zheng-xun, J., Guo-hui, M., Wen-nan, S., Hai-ying, L., Mei-lan, X., \& Yan, L. (2010). Dynamics between lodging resistance and chemical contents in japonica rice during grain filling. Rice Science, 17(4), 311-318. http://dx.doi.org/10.1016/S1672-6308(09)60032-9

Gao, X., Zou, C., Wang, L., \& Zhang, F. (2006). Silicon decreases transpiration rate and conductance from stomata of maize plants. Journal of Plant Nutrition, 29, 1637-1647. http://dx.doi.org/10.1080/01904160 600851494

Hayasaka, T., Fujii, H., \& Namai, T. (2005). Silicon content in rice seedlings to protect rice blast fungus at the nursery stage. Journal of General Plant Pathology, 71(3), 169-173. http://dx.doi.org/10.1007/s10327-0050182-7

Husnain, Wakatsuki, T., Setyorini, D., Hermansah, Sato, K., \& Masunaga, T. (2008). Silica availability in soils and river water in two watersheds on Java Island, Indonesia. Soil Sci Plant Nutr, 54, 916-927. http://dx.doi.org/10.1111/j.1747-0765.2008.00313.x

Husnain, Aflizar, Darmawan, \& Masunaga, T. (2011). Study on soil silicon status in Indonesia. Proceeding of the $5^{\text {th }}$ International Conference on Silicon in Agriculture, September 13-18, 2011, Beijing.

IITA. (1979). Selections methods for soil and plant analyses. Manual Series No. 1. Ibadan, Nigeria.

Imaizumi, K., \& Yoshida, S. (1958). Edaphological studies on silicon supplying power of paddy field. Bull Natl Inst Agric Sci, B8, 261-304

Indonesian Soil Research Institute. (2005). Petunjuk Teknis Analisis Kimia Tanah, Tanama, Air dan Pupuk. Balai Penelitian Tanah (Indonesian Soil Research Institute), Bogor, Indonesia.

International Rice Research Institute (IRRI). (1996). Standard evaluation system for rice (4th ed.). Los Banõs, Philippines: IRRI.

Ishimaru, K., Shirota, K., Higa, M., \& Kawamitsu, Y. (2001). Identification of quantitative loci for adaxial and abaxial frequencies in Oryza sativa. Plant Physiol Biochem, 39, 173-177. http://dx.doi.org/10.1016/ S0981-9428(00)01232-8

Jones, L. H. P., \& Handreck, K. A. (1967). Silica in soils, plants and animals. AdvAgron, 19, $107-149$. http://dx.doi.org/10.1016/S0065-2113(08)60734-8

Jones, H. G. (1992). Plants and microclimate (2nd ed.). Cambridge: Cambridge University press.

Kadar, D., \& Sudijono. (1993). Geological map of the Rembang quadrangle, Jawa. Bandung, Indonesia: Geological Research and Development Centre.

Kar, S., Varade, S. B., Subramanyam, T. K., \& Ghildyal, B. P. (1974). Nature and growth pattern of rice root system under submerged and unsaturated conditions. I1 Riso, 23, 173-179.

Korndorfer, G. H., \& Lepsch, I. (2001). Effect of silicon on plant growth and crop yield. In L. E. Datnoff, \& G. H. Korndorfer (Eds.), Studies in plant science (pp. 133-147). Amsterdam: Elsevier. 
Koyama, T., \& Sutoh, M. (1987). Simultaneous multi element detemination of soil, plant and animal samples by inductively coupled plasma emission spectrophotometry. Jpn. J. Soil Sci. Plant Nutr, 58, 578-585.

Kramer, P. J. (1988). Changing concepts regarding plant water relations. Plant Cell Environ, 11, $565-568$. http://dx.doi.org/10.1111/j.1365-3040.1988.tb01796.x

Li, H. J., Zhang, X. J., Li, W. J., Xu, Z. J., \& Xu, H. (2009). Lodging resistance in japonica rice varieties with different panicle types. Chinese Journal of Rice Science, 23(2), 191-196.

Ma, J. F., \& Takahashi, E. (2002). Soil, fertilizer, and plant silicon research in Japan. Amsterdam: Elsevier.

Ma, J. F., \& Yamaji, N. (2006). Silicon uptake and accumulation in higher plants. Trends Plant Sci, 11, $392-397$. http://dx.doi.org/10.1016/j.tplants.2006.06.007

Mamaril, C. P., Wihardjaka, A., Wurjandari, D., \& Suprapto. (1994). Potassium fertilizer management for rainfed lowland rice in Central Java, Indonesia. Philipp. J. CropSci, 19, 101-109.

Marin, J. A. (2003). High survival rates during acclimatization of micropropagated fruit tree rootstocks by increasing exposures to low relative humidity. Acta Horticulturae, 616(1), 139-142. http://dx.doi.org/ 10.17660/ActaHortic.2003.616.13

Martin, C., \& Glover, B. J. (2007). Functional aspects of cell patterning in aerial epidermis. Current Opinion in Plant Biology, 10, 70-82. http://dx.doi.org/10.1016/j.pbi.2006.11.004

McLean, E. O. (1982). Soils pH and lime requirement. In A. L. Page., E. Baker, E. J. Ellis, et al. (Eds.), Methods of Soil Analysis (No. 9, Part 2, pp. 199-209). Madison, Wisconsin.

Mishra, A. (2012). Intermittent irrigation enhances morphological and physiological efficiency of rice plants. Agriculture (Pol'nohospodárstvo), 58(4), 121-130. http://dx.doi.org/10.2478/v10207-012-0013-8

Ministry of Agriculture of Republic Indonesia. (2016). Harvested area, yield and productivity of rice. Basis data of agriculture. Retrieved January 5, 2016, from https://aplikasi.pertanian.go.id/bdsp/hasil_kom.asp

Nardini, A., Salleo, S., \& Tyree, M. T. (2002). Ecological aspects of water permeability of roots. In Y. Waisel, A. Eshel, \& U. Kafkafi (Eds.), The Hidden Half(3rd ed., pp. 683-698). New York: Marcel Dekker.

Osaki, M., Shinano, T., Matsumoto, M., Zheng, T., \& Tadano, T. (1997). A root-shoot interaction hypothesis for high productivity of field crops. Soil Science and Plant Nutrition, 43, 1079-1084. http://dx.doi.org/ 10.1007/978-94-009-0047-9_215

Prabhu, A. S., Filho, M. P. B., Datnoff, L. E., \& Snyder, G. H. (2001). Silicon from rice disease control perspective in Brazil. In L. E. Datnoff., G. H. Snyder, \& G. H. Korndorfer (Eds.), Silicon in agriculture (pp. 293-311). Amsterdam: Elsevier, Amsterdam. http://dx.doi.org/10.1016/S0928-3420(01)80022-7

Quaker, N. R., Klucker, P. D., \& Chang, G. N. (1970). Calibration of inductively coupled plasma emission spectrophotometry for analysis of the environmental materials. Anal. Chem, 51, 885-895.

Radoglou, K. M., \& Jarvis, P. G. (1990). Effects of $\mathrm{CO}_{2}$ enrichment on four polar clones. Leaf surface properties. Ann Bot, 65, 627-632.

Sadandan, A. K., \& Varghes, E. J. (1968). Studies on the silicate nutrition of rice in the laterite soil of Keral. I. Effect on growth and yield. MadrasAgri J, 11, 261-264.

Sahrawat, K. L. (2000). Elemental composition of the rice plant as affected by iron toxicity under field conditions. Commun Soil Sci Plant Anal, 132, 2819-2827. http://dx.doi.org/10.1080/0010362000937063

Savant, N. K., Snyder, G. H., \& Datnoff, L. E. (1997). Silicon management and sustainable rice production. AdvAgron, 56, 151-199. http://dx.doi.org/10.1016/S0065-2113(08)60255-2

Seebold, K. W. (1988). The influence of silicon fertilization on the development and control of blast caused by Magnoporthe grisea (Hebert) Barr. in upland rice (Unpublished doctoral dissertation). University of Florida, Gainesville.

Shimoyama, S. (1958). Effects of silicic acid on the lodging tolerance and the alleviation of wind damage to rice plants in the growth stage toward heading. In A. Okuda (Ed.), Studies on the advancement of yield potentials of crop plants with the adoption of silisic acid inputs (Vol. 48, pp. 57-59). Rept Res by Min Educ.

Singer, M. J., \& Munns, D. N. (2006). Soils: An introduction (6th ed.). New Jersey: Pearson Prentice Hall. 
Siregar, A. F., Husnain, Sato, K., Wakatsuki, T., \& Masunaga, T. (2016). Empirical study on effect of Silicon application on rice blast disease and plant morphology in Indonesia. Journal of Agricultural Science, 8(16), 137-148. http://dx.doi.org/10.5539/jas.v8n6p137

Spence, R. D., Wu, H., Sharpe, P. J. H., \& Clark, K. G. (1986). Water stress effects on guard cell anatomy and the mechanical advantage of the epidermal cells. Plant, Cell and Environment, 9, 197-202. http://dx.doi.org/10.1111/1365-3040.ep11611639

Sumida, H. (1991). Characteristics of silica dissolution and adsorption in paddy soils: Application to soil test for available silica. Jap J Soil Sci Plant Nutr, 62, 378-385.

Sumida, H. (1992). Silicon supplying capacity of paddy soils and characteristics of silicon uptake by rice plants in cool regions in Japan. Bull Tohoku Agric Exp Stn, 85, 1-46.

Statistic Indonesia. (2016). Retrieved January 6, 2016, from http://www.bps.go.id/linkTabelStatis/view/id/1349

Taylor, H. M., \& Gardner, H. R. (1963). Penetration of cotton seedling taproots as influenced by bulk density, moisture content and strength of the soil. Soil Sci, 96, 153-156. http://dx.doi.org/10.1097/00010694-1963 09000-00001

Terashima, K., Ogata, T., \& Akita, S. (1994). Eco-physiological characteristics related with lodging tolerance of rice in direct sowing cultivation. II. Root growth characteristics of tolerant cultivars to root lodging. Japanese Journal of Crop Science, 63, 34-41. http://dx.doi.org/10.1626/jcs.63.34

Thomas, G. W. (1982). Exchangeable cations. In A. L. Page (Ed.), Methods of soil analysis, Part 2 Chemical and microbiological properties. Agronomy (Vol. 9, pp. 159-165).

Wang, H., \& Clarke, J. M. (1993b). Genotypic, intra plant and environmental variating in stomatal frequency and size in wheat. Can J Plant Sci, 73, 671-678. http://dx.doi.org/10.4141/cjps93-088

Wattanapayapkul, W., Polthanee, A., Siri, B., Bhadalung, N. N., \& Promkhambut, A. (2011). Effects of silicon in suppressing blast disease and increasing grain yield of organic rice in Northeast Thailand. Asian Journal of Plant Pathology, 5, 134-145. http://dx.doi.org/10.3923/ajppaj.2011.134.145

Wibowo, B. S. (2011). Sebaran dan perkembangan OPT padi. Prosiding Seminar Nasional Penyakit Tungro. Makassar, Indonesia.

Wihardjaka, A., Kirk, G. J. D., Abdulrachman, S., \& Mamaril, C. P. (1999). Potassium balances in rainfed lowland rice on light textured soil. Field Crop Res, 64, 237-247. http://dx.doi.org/10.1016/S0378-4290 (99)00045-3

Winslow, M. D. (1995). Silicon: A new macronutrient deficiency in upland rice. CIAT Working Document No. 149. Cali, Colombia.

Winslow, M. D., Okada, K., \& Correa-Victoria, F. (1997). Silicon deficiency and the adaptation of tropical rice ecotypes. Plant Soil, 188, 239-248. http://dx.doi.org/10.1023/A:1004298817861

Xu, F. F., Zeng, X. C., Shi, Q. H., \& Ye, L. M. (2007). Effects of different irrigation patterns on the growth of rice root. Agric Res Arid Areas, 25(1), 102-104.

Xuan, T. H., \& Gergon, E. B. (2016). Strategies for the management of rice pathogenic fungi. In S. K. Desmukh, J. K. Misra., J. P. Tewari, \& T. Papp (Eds.), Fungi: Application and management strategies (pp. 396-423). Boca Taron: CRC Press.

Yang, H. J., Yang, R. C., Li, Y. Z., Jiang, Z. W., \& Li, J. S. (2000). Relationship between culms traits and lodging resistance of rice cultivars. Fujian J AgricSci, 15(2), 1-7.

Yoshida, S., Ohnishi, Y., \& Kitagishi, K. (1962). Chemical forms, mobility, and deposition of silicon in the rice plant. Soil Sci Plant Nutr, 8, 107-111. http://dx.doi.org/10.1080/00380768.1962.10430992

Yoshida, S. (1965). Chemical aspects of the role of silicon in physiology of the rice plant. Bull Natl Inst Agric Sci Series, B 15, 1-58.

Yoshida, S. (1981). Fundamentals of rice crop science (p. 269). Los Banos Laguna, Philippines: International Rice Research Institute.

Yoshinaga, S. (2005). Improved lodging resistance in rice (Oryza sativa L.) cultivated by submerged direct seeding using a newly developed hill seeder. JARQ, 39(3), 147-152. http://dx.doi.org/10.6090/jarq.39.147 
Zargar, S. M., \& Agnihotri, A. (2013). Impact of silicon on various agro-morphological and physiological parameters in maize and revealing its role in enhancing water stress tolerance. J Food Agric, 25(2), $138-141$. http://dx.doi.org/10.9755/ejfa.v25i2.10581

Zhu, Y. Y., Fang, H., Wang, Y. Y., Fan, J. X., Yang, S. S., Mew, T. W., \& Mundt, C. C. (2005). Panicle blast and canopy moisture in rice cultivar mixtures. Phytopathology, 95, 433-438. http://dx.doi.org/10.1094/PHYTO $-95-0433$

\section{Copyrights}

Copyright for this article is retained by the author(s), with first publication rights granted to the journal.

This is an open-access article distributed under the terms and conditions of the Creative Commons Attribution license (http://creativecommons.org/licenses/by/4.0/). 